\title{
施設再配置を考慮した公共施設の段階的総量適正化に関する研究 一町田市を対象としたケーススタディと評価プロセスの検証－ \\ A STUDY ON PHASED OPTIMIZATION OF THE GROSS AREA OF PUBLIC FACILITIES VIA FACILITY RELOCATION
}

- Verification of the evaluation process and case studies in Machida-city -

$$
\begin{gathered}
\text { 大舘峻一*, 角田 誠**, 李 祥 準*** } \\
\text { Shunichi OHDATE, Makoto TSUNODA and Sangjun YI }
\end{gathered}
$$

\section{Shunichi OHDATE, Makoto TSUNODA and Sangjun YI}

\begin{abstract}
It is necessary for local governments to evaluate the total number of public facilities in consideration of facility relocation. Owing to the aging of several public facilities and change in the future demographic, the financial situation deteriorates.

In this study, we categorized public facilities according to "Building," "Function," and "Location" to create an evaluation method for public facilities. Further, we propose a maintenance method of a public facilities group via facility relocation using available data collected from each local government.

In conclusion, we have proposed a long-term utilization policy considering utility after completion of useful life of the facility. Additionally, the maintenance method and total optimization process of the facility via facility relocation was presented, which was validated by verifying with the target local government.
\end{abstract}

keywords : Public facility, Facility relocation, Facility total optimization,

Facility evaluation, Public facilities management 公共施設, 施設再配置, 施設総量適正化, 施設評価, 公共 FM

\section{1. 研究概要}

\section{$1-1$ 研究の背景と目的}

戦後の高度経済成長期を経て、日本では大量の公共施設が整備さ れ、経年とともに修繥・建替の必要性が増加してきた。加えて自治 体の財政状況を考慮すると施設総量を適正にする必要があり、これ ら公共施設ストックを良質な状態で、適正な費用で更新していくた めに、改修·建替·統廃合等の適切な判断が重要となる。そのためには、 他施設の状況を踏まえた複合的な計画が求められるが、対象となる 施設を取り巻く状況は老朽度・利用状況・立地条件など様々であり、 自治体全体として総合的かつ長期的に整備方針を決めることが困難 になっている。さらに、2014 年には総務省からの「公共施設等総合 管理計画の策定要請」注 1)、加えて同年に国土交通省から「まちづく りのための P R E 有効活用ガイドライン」注 2) が発表され、施設再配 置を含めた公共施設マネジメントが急務とされている。これらから、 施設再配置を考慮した公共施設の総量適正化のための必要データの あり方とその整備プロセスを構築することが喫緊の課題である。

本研究では、自治体の人口や財政状況の変化といった将来予測に もとづき、施設再配置を考慮した段階的・経時的な視点に立った公 共施設総量適正化プロセスの考え方を示寸とともに、実際の自治体 を対象とした検証からその妥当性を明らかにすることを目的とする。

\section{1-2 既往研究との位置づけ}

公共施設の施設評価に関する研究としては、首都大学研究チーム ら (2008年) ${ }^{1)}$ が、東京都多摩市を対象に126の公共施設をデータ ベース化し、貸室利用特性・物理的特性（建物）、施設運営管理 費・利用者需要（機能）、施設配置（立地）の分析を行っている。 しかし、3つの観点の個別分析にとどまっており、長期的且つ総合 的な視点にもとづいた施設再編方法は明らかにされていない。また、 増川ら（2011年） ${ }^{2)}$ は建物自体のハード評価と利用度等のソフト評価 から施設の活用方針を導いているが、施設再配置に資する評価まで 及んでいない。佐久間ら (2012年) ${ }^{3)}$ は増川らの研究を受け、公共施 設の集約化に向けた評価及び総量適正化プロセスの再整理を行って いるが、自治体全体の公共施設状沉と将来予測に基づいた施設選定 までは及んでいない。恒川淳基ら（2013年） ${ }^{4)}$ は建物の劣化状況（以 降、劣化度と呼ぶ。）を施設経年数と大規模修繥からの経過年をも とに算出する方法を提示しているが、精度が低いことが問題である。 川野ら（2012年） ${ }^{5)}$ による一連の研究では、施設評価に取り組んでい る自治体の分析から施設再配置に資する評価指標を提案、再配置シ ミュレーションを行っているが、経時的視点に立った整備方法まで は明らかにしていない。また、恒川和久ら（2015年）6) は用途にとら われない市民ニーズに応じたマネジメント方法の構築を目的とし、
* 独立行政法人都市再生機構 修士(工学)

** 首都大学東京大学院都市環境科学研究科建築学域 教授・博士 (工博)

*** 関東学院大学建築環境学部 専任講師 ·博士 (工学)
Urban Renaissance Agency, M.Eng.

Prof., Dept. of Architecture and Building Engineering, Graduate School of Urban Environmental Sciences, Tokyo Metropolitan Univ., Dr.Eng.

Assist. Prof., Dept. of Architecture and Environmental Design, Kanto Gakuin Univ., Dr.Eng. 
公共施設をアクティビティの観点から分析しているが、施設の具体的 な整備方法まで及んでおらず、施設再配置に言及したものではない。

施設の評価方法、整備プロセスを明らかにした研究は多く存在する が、本研究が目指寸各自治体が収集可能なデータにもとづいた段階 的・経時的な視点に立った施設再配置と施設総量適正化に向けた方法 論の研究はされていない。

\section{2. 公共施設の評価}

建物の劣化状況、利用者ニーズの変化、施設周辺の人口変化等、公 共施設を取り巻く状況が複雑であるため、施設整備状況を整理し、そ れらを総合的に評価する必要がある。既往研究 ${ }^{1)} \sim$ 4) と既存の基準 78) の知見から、公共施設に対する評価基準を新たに「品質」・機能」・立地」 の3つに分け、図 1 に示寸評価基淮を構築した注3)。

\section{2-1. 品質に対する評価}

品質評価では、建物の耐震性の有無と外壁・内装・屋上防水・設備 の改修の実施状況を判定する。棟ごとに建物の品質を把握し、施設全 体の面積と各棟の面積を按分して算出する。

（1）耐震性に関する判定

施設を継続的に利用するかを判断するために、現状の施設が而震性 を有しているかを判断することは重要な項目となる。評価項目、評価 の基準については、既往研究 2)3) で整理されていた耐震性に関する判定 をもとに、再整理を行った注 4)。耐震性の判定は、フローに沿って築年 数から新耐震基準を満たしているか、耐震補強を実施しているか、及 び而震診断の結果から判断する。

(2) 劣化度に関する判定

施設の継続的な利用を判断するために、現状の施設の劣化度を判定 する必要がある。本研究では改修を行う部位を「外壁」・「内装」・屋
上防水」・設備」と分類し、新たな劣化度の算出方法を構築する。まず、 参考文献 ${ }^{7)}$ より経年ごとに掛かる改修費用から各部位の改修周期の設 定を行う注 5)。各部位の経年ごとの改修費用と累計改修費用を図 2 に示 す。経年ごとの改修費用を見ると、外壁は $11 \sim 15$ 年、 $26 \sim 30$ 年、 $36 \sim 45$ 年に多いことから 15 年を、内装は約 10 年ごとの小規模な改 修費と 30 年程度での大規模な改修費が掛かることから 20 年を、屋上 防水・設備は、 $16 \sim 20$ 年、 $26 \sim 30$ 年、36〜 40 年に改修費用が多い ことから 20 年を改修周期とした。さらに、各部位にかかる耐用年数ま での累計改修費用は、最も高いのが設備で約 9 万円 / $\mathrm{m}^{2}$ 、最も低いの が屋上防水で約 2 万円 / $\mathrm{m}^{2}$ と差があることから、劣化度算出式の重み づけの際に利用する。これらの結果と既往研究 4) の劣化度算出方法を もとに、新たに構築した劣化度の算出方法を図 3 に示す注 6 。

以上の判定より、品質に対する評価結果は図 1 - (1)のようになる。

\section{$2-2$. 機能に対する評価}

機能評価では、住民に機能 (公共サービス) を十分に提供しているか、 及び適切な費用で機能を運営できているかの判断を行う。その際、複 数機能を提供する施設もあるため、機能ごとに状況を把握する。

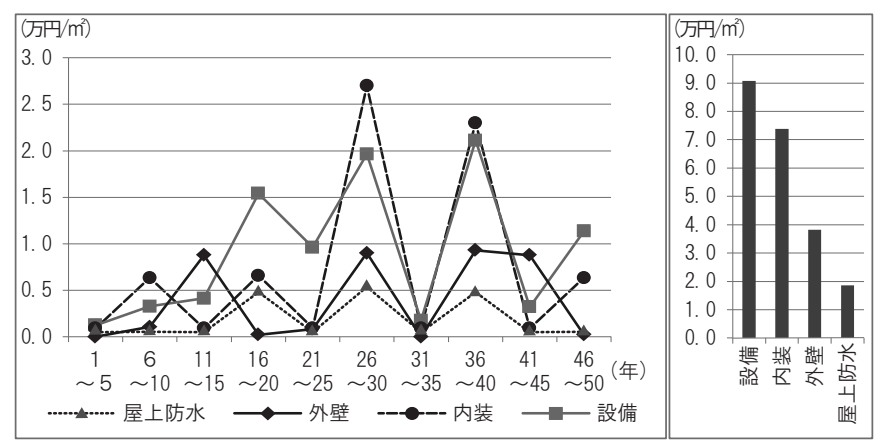

図 2 各部位の年次別改修費用（左）と耐用年数までの累計改修費用（右）

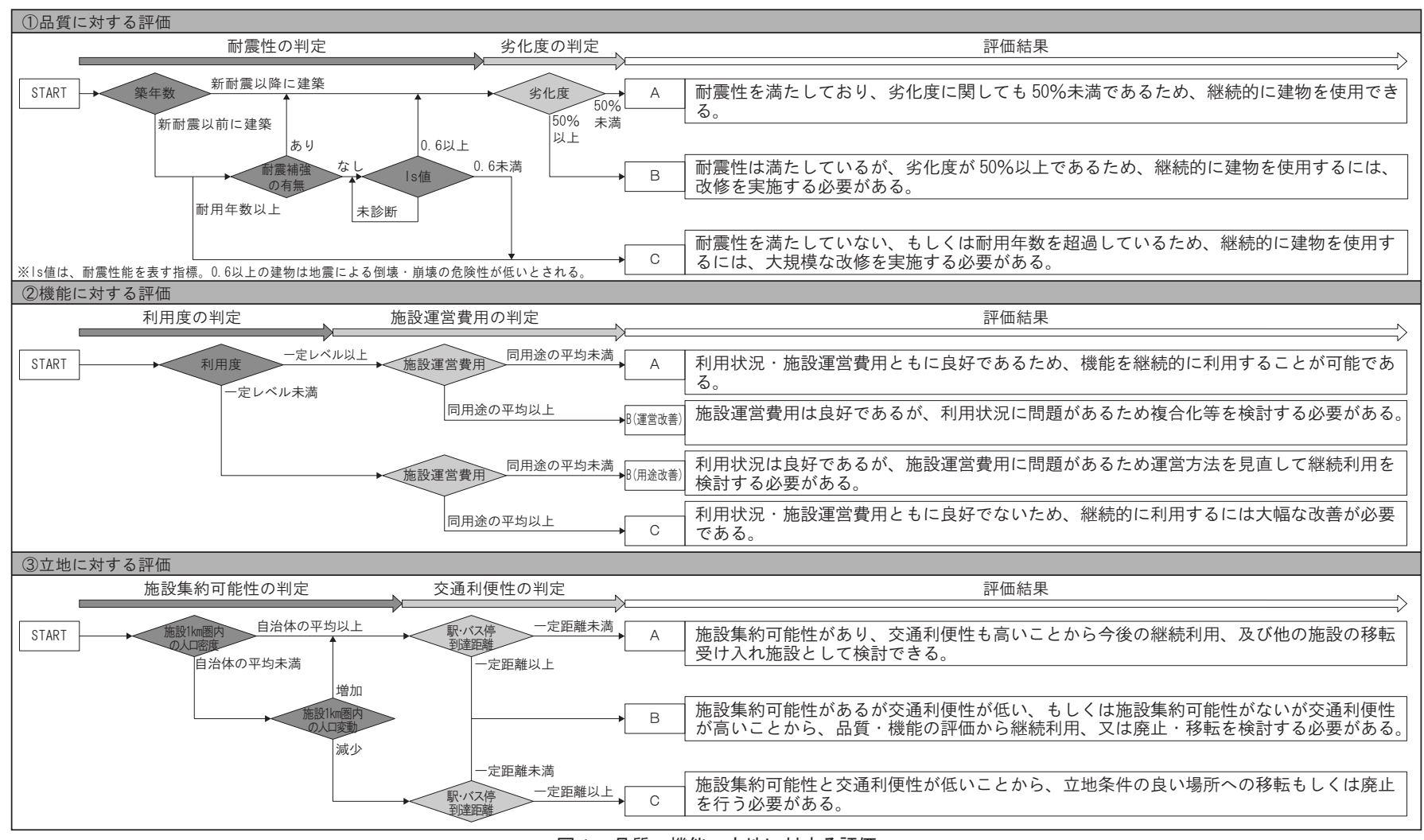

図 1 品質・機能・立地に対する評価 
（1）利用度に関する判定

利用度の判定では、機能が余剩に供給されていないかを判断する。 利用度が低い施設は、過剩供給の可能性があるため他の機能との集約 もしくは廃止を検討する必要がある。参考文献 ${ }^{8)}$ の利用度の判定をも とに本研究における評価項目として再整理を行い、表 1 に示寸事務庁 舎・学校・貸館系の公の施設 ・ 貸館系以外の公の施設に分類し利用度 を判断した。学校の利用度判定については、文科省が定める学校設置 基準の校舎面積との比を用いる。

\section{（2）施設運営費用に関する判定}

施設運営費用では、施設の機能が適切な費用で運営されているかを

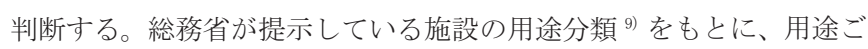
とに施設運営費用の平均值を算出し、それらの比較で評価を行った。

以上の判定より、機能に対する評価結果は図 1 -(2)のようになる。

\section{2 -3. 立地に対する評価}

立地評価では将来的な施設周辺の人口変動からみた施設集約の可能 性、及び施設への交通利便性の観点から判断を行う。

（1）施設集約可能性に関する判定

施設集約可能性に関する判定方法を表 2 に示す。将来的な施設周辺 の人口変動から、今後その立地に対して施設集約をすることが有効か を判断する。ここでは、施設からの距離 $1 \mathrm{~km}$ 圈内の将来的な人口と人 口密度の変動を表にしたがって判定を行う注》。

\section{（2）交通利便性に関する判定}

交通利便性に関する判定方法を表 3 に示す。施設から駅・バス停ま での到達距離にもとづき、交通利便性を判断する。駅到達距離は、全 施設の駅到達距離の平均值を閾值にとり、バス停到達距離は、バス停 までの徒歩圈域 $400 \mathrm{~m}$ 閾値として設定した。

以上の判定より、立地に対する評価結果は図 1 -(3)のようになる。

\section{2-4. 評価にもとづいた施設の活用方針}

品質・機能・立地の 3 つの評価を用いることで、施設の現時点と 耐用年数超過後の活用方針が検討可能になる。表 4 に 3 つの評価に もとづいた施設の経時的な活用方針の内容、図 4 に施設の活用方針 を導き出すための判定マトリクスを示す。

それぞれの活用方針としては、「長期的継続利用」は、施設の現在 の状況がよいため、継続的な利用を行い、また将来的な状況もよい ため、耐用年数超過後は建替を検討する。「長期的複合化利用」は、 機能評価が良好でないことから複合化を行うが、将来的な状況がよ いため、耐用年数超過後は建替を検討する。「縮減的継続利用」は、 施設の現在の状沉がよいため、継続的な利用を行うが、将来的な状 況が悪いため、耐用年数超過後は廃止・移転を検討する。「縮減的複 合化利用」は、機能評価が良好でないことから複合化を行い、一方 で将来的な状況も悪いため、耐用年数超過後は廃止・移転を検討する。 「機能停止・移転」は施設の現在の状況、将来的な状況が悪いため廃止・ 移転を検討する。これらの施設の活用方針を用いることで、施設総 量適正化策検討の意思決定を簡易にすることが可能となる。

\section{3. 公共施設の段階的総量適正化のプロセス}

既往研究 1) 4) 及び、提示した施設評価手法を踏まえ、図 5 に示寸 新たな公共施設の総量適正化プロセスを構築した。

\section{(1) 準備段階}

公共施設の総量適正化を実現していくために、必要となるデータ
の収集、整理を行う。表 5 に総量適正化のために必要となるデータ の一覧を示す。自治体の基本情報は、人口・財政状況に関するデー タや国立社会保障・人口問題研究所が公開している自治体の将来人 ロデータを収集する。施設の基本情報としては、住所・竣工年・延

\begin{tabular}{|c|c|}
\hline $\begin{array}{l}\text { 劣化度 }=\left(\frac{T_{n}}{T}+X\right) \times \frac{1}{2} \\
X=\left\{\left(\frac{T_{i}}{20}+\frac{T_{e q}}{20}\right) \times 3+\frac{T_{e}}{15} \times 2+\frac{T_{r}}{20}\right\} \times \frac{1}{9}\end{array}$ & 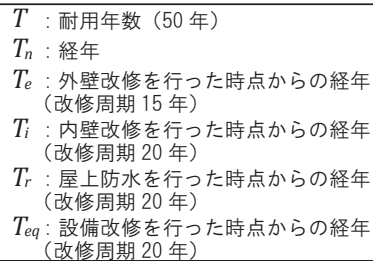 \\
\hline
\end{tabular}

图 3 劣化度の算出方㳊4)7》修期 20 作成

表 1 利用度の判定方法 ${ }^{8)}$ より作成

\begin{tabular}{|c|c|c|}
\hline 分類 & 評価内容 & 評価基準 \\
\hline \multirow{2}{*}{ 事務庁舎 } & \multirow{2}{*}{ 職員一人当りの床面積 } & \begin{tabular}{l|l}
$\mathrm{x}$ & $15 \mathrm{~m}^{2} /$ 人未満 \\
\end{tabular} \\
\hline & & ○ $15 \mathrm{~m}^{2} /$ 人以上 \\
\hline 学校 & 実際の床面積と学校設置基準による床面積の比 & \begin{tabular}{l|l}
$\times$ & 学校設置基準未満 \\
$\bigcirc$ & 学校設置基準を満たす
\end{tabular} \\
\hline $\begin{array}{l}\text { 公の施設 } \\
\text { (貸館系) }\end{array}$ & 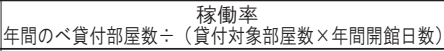 & \begin{tabular}{l|l}
$\times$ & 稼動率50\%未満 \\
0 & 稼働率50\%以上
\end{tabular} \\
\hline \multirow{2}{*}{ (貟の館系以設) } & \multirow{2}{*}{ 利用者数（実績）と利用者数（計画）の比 } & \begin{tabular}{c|c}
$\times$ & $\begin{array}{l}\text { 計画を下回る利用状況 } \\
\text { (績/計画が1未満) }\end{array}$ \\
\end{tabular} \\
\hline & & \begin{tabular}{l|l} 
\\
\end{tabular} \\
\hline
\end{tabular}

表 2 施設集約可能性の判定方法

\begin{tabular}{|c|c|c|c|c|}
\hline \multicolumn{3}{|c|}{ 施設集約可能性の判定 } & \multicolumn{2}{|r|}{ 評価基準 } \\
\hline 人口増減 & 増加 & 減少 & 人口増減 & $\begin{array}{l}\text { 2050年における施設 } 1 \mathrm{~km} \text { 圏内の人口が増加傾向 } \\
\text { にあるか減少傾向にあるか判断する }\end{array}$ \\
\hline 平均以上 & $\mathrm{O}$ & $\mathrm{O}$ & 人口密度 & 2050年における施設 $1 \mathrm{~km}$ 圏内の人口密度と \\
\hline 平均未満 & 0 & $x$ & 人口缶率 & 2050年時点での自治体全体の人口密度とを比較する \\
\hline
\end{tabular}

表 3 交通利便性の判定方法

\begin{tabular}{|c|c|c|c|c|}
\hline \multicolumn{3}{|c|}{ 交通利便性の判定 } & \multicolumn{2}{|r|}{ 評価基準 } \\
\hline & & 距離 & 5離 & 内全施設の駅まで \\
\hline バス & 未 & 以上 & 巳離 & \\
\hline \begin{tabular}{l|l} 
到達距離 & 末満 \\
以上
\end{tabular} & $\begin{array}{l}0 \\
0\end{array}$ & $\frac{0}{x}$ & 亭到達距離 & $\begin{array}{l}\text { 徒歩でバス停へ到達す } \\
\text { の00m を闇値とする }\end{array}$ \\
\hline
\end{tabular}

表 4 評価をもとにした経時的な施設の活用方針

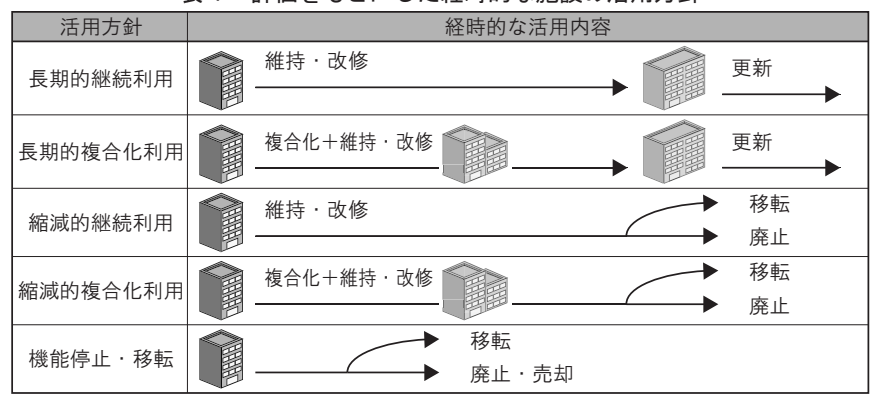

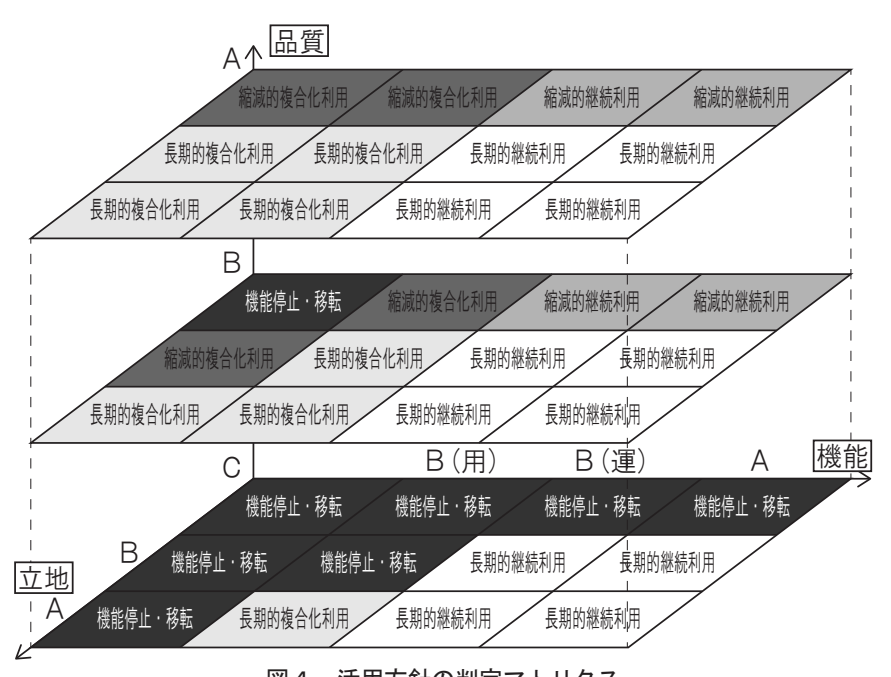

図 4 活用方針の判定マトリクス 
床面積といった施設に関する情報を収集する。また、品質に関する データは、耐震性の状況、最近の外壁・内装・屋上防水・設備に対 する工事履歴を把握し、棟ごとに整理を行う。機能に関するデータは、 施設の利用状況、総務省基準モデルの公会計から抽出した施設運営 費用を機能ごとに整理する。立地に関するデータは、国土交通省が 国土数值情報として公開している将来推計人ロメッシュデータと駅・ バス停までの実際の距離を施設ごとに整理を行う注8)。

\section{（2）削減目標面積の決定段階}

自治体の財政状況に見合った施設総量までに削減していくため、 将来的に公共施設に費やせる費用に合わせて、施設総量の削減目標 面積を決定する必要がある。将来的に公共施設に関わる費用（施設 運営費用・維持更新費用）を推計し ${ }^{10)}$ 、現状として公共施設に掛け ている費用との不足分を削減目標費用とする。次に、公共サービス を保ちながら施設を削減するために、機能ごとの削減量を決定する。 まず、人口変動を考慮した適正な施設量を検討していく。現時点で の住民一人当たりの延べ床面積を適正な施設量として、各機能を利 用する年齢区分の将来人口の増減率を掛けて算出する。さらに、施 設ごとの公共施設に関わる費用と施設総面積を考慮して、削減目標 費用に到達するように機能ごとの施設削減量を決定する。

\section{（3）公共施設の評価段階・整備方法検討段階}

公共施設の評価段階では、今後の施設の活用方法を効率的に決定 寸るために、2 章で示した施設評価を行い、判定マトリクスで各施 設の活用方針を判定する。

整備方法検討段階では、まず判定した活用方針をもとに、機能ご とに建替・複合化・廃止・移転を行う施設を検討し、前項で決定し た機能ごとの削減目標面積まで整備方法を決定する。次に、廃止・ 移転による住民提供サービスの低下を考慮するため、各地域におけ る主要な機能の状況、耐用年数、前段階で決定した活用方法を表示 した「経時的地域実態マップ」を作成し、他施設との複合的な整備 方法を計画する。複合的な整備方法の計画にあたっては、表 6 に示 す立地タイプにより計画方法が異なるため留意が必要となる ${ }^{911112)}$

さらに、ここまでに検討してきた整備方法は、自治体全体で見る と複数で、かつ整備期間が重複するため、決定した整備方法を整備 期間と整備対象施設の劣化度から再度序列化を行う。これにより、 自治体全体としての長期的かつ経時的な施設再編方法が決定できる。

\section{（4）具体的計画段階·実行段階·検証段階}

具体的計画段階では、公共施設の位置関係を把握し、統合の可能 性についてさらに検討する。また、周辺の民間施設の状沉を確認し、 テナントとしての使用の可否、整備する施設への誘致可能性の有無 を検討する。実行段階では計画を実際に行い、さらに検証段階では 実行した計画がどのような結果をもたらしたかの検証を行う。これ らの検証結果を次の計画に活かし、ここまでの整備計画、評価方法 を定期的に見直し、必要データを積み重㸚ることで、より正確な評 価結果と整備計画につながる。

\section{4. 町田市をケーススタディとした総量適正化プロセスの検証}

（1）削減目標面積の決定段階

\section{1 ) 将来的な財政状況の確認}

図 7 に町田市の公共施設に関わる費用の推計を示す注 10)。現在の公 共施設に関わる費用は維持更新費用 74 億円注 ${ }^{11}$ 、施設運営費用 100

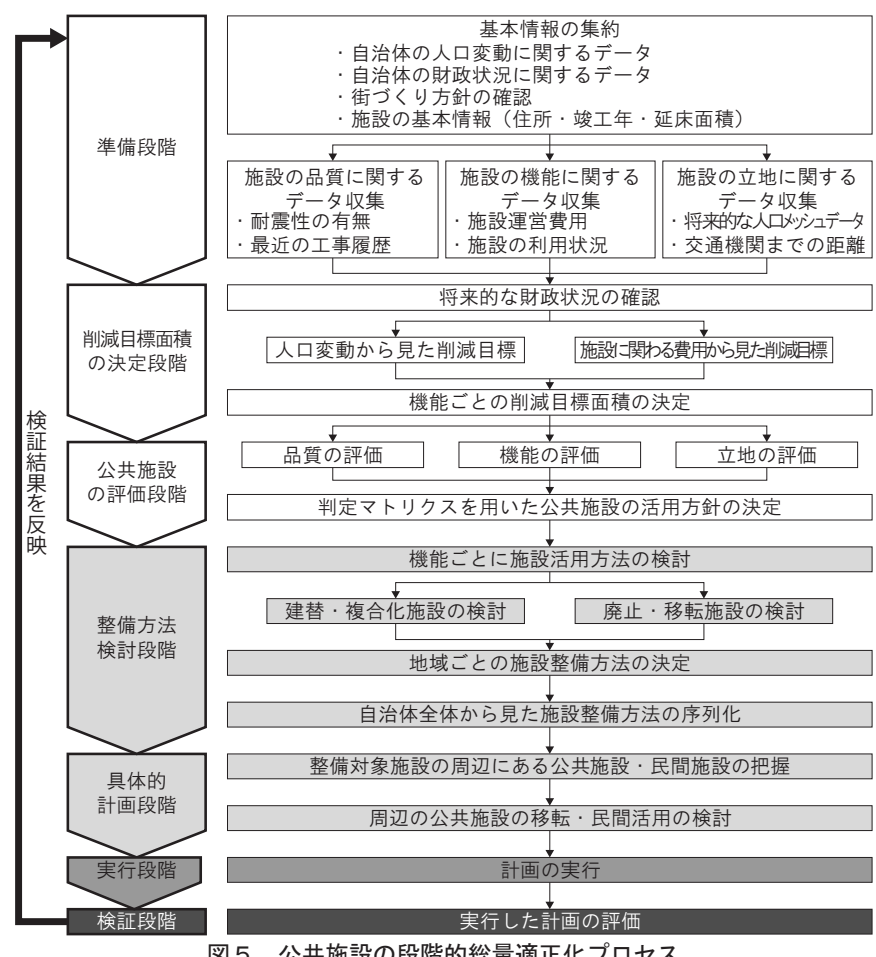

表 5 総量適正化に必要なデーター覧

\begin{tabular}{|c|c|c|c|c|c|}
\hline \multicolumn{3}{|c|}{ 収集目的 } & $\begin{array}{l}\vec{\Gamma}=タ 0 \\
\text { 集め方 }\end{array}$ & 必要データ & 収集方法 \\
\hline \multirow{3}{*}{\multicolumn{3}{|c|}{ 自治体の基本情報 }} & \multirow{3}{*}{$\begin{array}{l}\text { 自治体 } \\
\text { として }\end{array}$} & これまでの財政状況 & 自治体の統計 \\
\hline & & & & これまでの人口変動 & 自治体の統計 \\
\hline & & & & 将来的な人口変動 & 国立社会保障·人口問題研究 \\
\hline \multirow{7}{*}{\multicolumn{3}{|c|}{ 施設の基本情報 }} & \multirow{2}{*}{$\begin{array}{l}\text { 施設 } \\
\text { ごと }\end{array}$} & 住所 & 自治体による把握 \\
\hline & & & & 築年数 & 自治体による把握 \\
\hline & & & \multirow{3}{*}{ 棵と } & 棟ごとの築年数 & 目治体による把握 \\
\hline & & & & 施設の用途分類 & 総務省の用途分類 \\
\hline & & & & 棟ごとの延床面積 & 自治体による把握 \\
\hline & & & 機能 & 施設の機能分類 & 自治体による分類 \\
\hline & & & ことと & 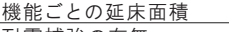 & 自治体による把握 \\
\hline \multirow{13}{*}{ 施設評価 } & \multirow{6}{*}{$\begin{array}{l}\text { 品質 } \\
\text { 評価 }\end{array}$} & \multirow{3}{*}{$\begin{array}{l}\text { 耐震性 } \\
\text { の判定 }\end{array}$} & \multirow{6}{*}{$\begin{array}{l}\text { 棟 } \\
\text { ごと }\end{array}$} & 耐震補強の有無 & 自治体による把握 \\
\hline & & & & $\begin{array}{l}\text { 耐震診断結果 } \\
\text { 等 }\end{array}$ & 自治体による把握 \\
\hline & & & & 外壁·内装·屋上防水·設備 & 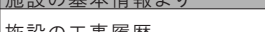 \\
\hline & & \multirow{3}{*}{$\begin{array}{l}\text { 劣化度 } \\
\text { の判定 }\end{array}$} & & の最近の工事履歴 & 施設の工事愎䠂 \\
\hline & & & & 棟ごとの築年数 & 施設の基本情報より \\
\hline & & & & 棟ごとの延床面積 & 施設の基本情報より \\
\hline & \multirow{3}{*}{$\begin{array}{l}\text { 機能 } \\
\text { 評価 }\end{array}$} & 利用度 & \multirow{3}{*}{$\begin{array}{l}\text { 機能 } \\
\text { ことと }\end{array}$} & 施設の利用状況 & 自治体による把握 \\
\hline & & & & 機能ごとの延床面積 & 施設の基本情報より \\
\hline & & $\begin{array}{l}\text { 施設運営 } \\
\text { 費用の判定 }\end{array}$ & & $\begin{array}{l}\text { 施設の運営費用 } \\
\text { 機能ごとの延庆面皘 }\end{array}$ & $\begin{array}{l}\text { 総務省基準モデルの公会計 } \\
\text { 施設の基本情報上り }\end{array}$ \\
\hline & \multirow{4}{*}{$\begin{array}{l}\text { 立地 } \\
\text { 評価 }\end{array}$} & \multirow{2}{*}{$\begin{array}{c}\text { 施設集約 } \\
\text { 可能性の判定 }\end{array}$} & \multirow{4}{*}{ 施設 } & $\begin{array}{l}\text { 将来的な施設 } 1 \mathrm{~km} \text { 圏内 } \\
\text { の人口密度 }\end{array}$ & 国土数值情報 \\
\hline & & & & 将来的な施設 $1 \mathrm{~km}$ 圏内 & |国土数值情報 \\
\hline & & \multirow{2}{*}{$\begin{array}{c}\text { 交通利便性 } \\
\text { の判定 }\end{array}$} & & 駅からの到達距離 & 実際の距離 \\
\hline & & & & バス停からの到達距離 & 実際の距離 \\
\hline
\end{tabular}

表 6 公共施設の機能と立地タイプ9) 11)12)より作成

\begin{tabular}{|c|c|c|c|c|}
\hline \multicolumn{2}{|r|}{ 機能 } & 立地タイプ & 総務省の用途分類 & 施設の例 \\
\hline \multicolumn{2}{|c|}{ 行政機能 } & 拠点·支所型 & $\begin{array}{c}\text { 行政系施設 } \\
\text { 学校教育系施設 }\end{array}$ & 市庁舎·出張所 \\
\hline \multicolumn{2}{|c|}{ 集会機能 } & 分散型 & 市民文化系施設 & ミュニティセンター・市民ホー \\
\hline \multicolumn{2}{|c|}{ 教育文化機能 } & 単独設置型 & 社会教育系施設 & 図書館·博物館 \\
\hline \multicolumn{2}{|c|}{ 学校教育機能 } & 分散型 & 学校教育系施設 & 小学校. 中学校 \\
\hline \multicolumn{2}{|c|}{ 医療保健機能 } & 単独設置型 & $\begin{array}{c}\text { 医療施設 } \\
\text { 保健·福祉施設 }\end{array}$ & 市民病院·診療所 · 保健所 \\
\hline \multicolumn{2}{|c|}{ 居住機能 } & 単独設置型 & 公営住宅 & 市営住宅 \\
\hline \multicolumn{2}{|c|}{ 子育て支援機能 } & 分散型 & 子育て支援施設 & 幼稚園・保育園・児童クラブ \\
\hline \multicolumn{2}{|c|}{ 障がい者支援機能 } & 分散型 & 保健·福 & 障がい者センター \\
\hline \multicolumn{2}{|c|}{ 高齢者支援機能 } & 分散型 & 保健·禅 & デイサービス \\
\hline \multicolumn{2}{|c|}{ 環境機能 } & 単独設置型 & $\begin{array}{l}\text { 供給処理施設 } \\
\text { 下水道施設 }\end{array}$ & クリーンセンター・下水施設 \\
\hline \multicolumn{2}{|c|}{\begin{tabular}{c|} 
スポーツ \\
レクリエーション機能|
\end{tabular}} & $\begin{array}{l}\text { 単独設置型 } \\
\text { 立地限定型 }\end{array}$ & \begin{tabular}{|c|} 
スポーツ \\
レクリエーション施設
\end{tabular} & $\begin{array}{c}\text { 体育館・市民プール } \\
\text { 青少年施設 }\end{array}$ \\
\hline \multicolumn{2}{|c|}{ 消防機能 } & 分散型 & 行政系施設 & 消防署・消防倉庫 \\
\hline \multicolumn{2}{|c|}{ 都市環境良化機能 } & 分散型 & 公匽 & 公園 \\
\hline \multicolumn{2}{|c|}{ その他 } & - & その他 & 斎場·駐車場·駐輪場 \\
\hline \multirow{2}{*}{$\begin{array}{l}\frac{1}{1} \\
\text { 地 } \\
\text { 多 } \\
\text { フ }\end{array}$} & $\begin{array}{c}\text { 立地限定型 } \\
\text { 単独設置型 }\end{array}$ & \multirow{2}{*}{\multicolumn{3}{|c|}{ 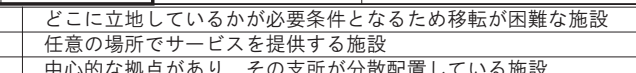 }} \\
\hline & 拠点・支所型 & & & 自治体内にバランスよく配置する必要がある施設 \\
\hline
\end{tabular}


億円の計 174 億円で、 2050 年には 163 億円になると推計された。また、 公共施設更新費用試算ソフト 注 122 から算出した適正な維持更新費用か ら、実際に必要となる費用は 205 億円となり、将来的には 42 億円の 不足が予測され不足分の施設量の削減が必要となる。

\section{2 ) 機能ごとの削減目標面積の決定}

表 8 に機能ごとの削減目標面積を決定したものを示す。まず、人 口変動を踏まえ削減目標を検討する。目標設定を行う時点での各機 能の延床面積を現人口に対する適切な施設量とし、将来における各 機能の延床面積は、施設利用者の年齢構成の人口変動に比例すると 考え、表 7 で示している各人口構成の変動率をかけた面積とした。 次に、施設にかかわる費用（維持更新費用・施設運営費用）を考虑 し削減目標を検討する。施設運営費用が大きい機能である「集会機 能」・「教育文化機能」の削減割合を大きくし、他機能に関しても削 減割合を調節することで目標費用までの削減を図った。

\section{（2）整備方法検討段階}

\section{1 ）機能ごとの建替・複合化・廃止・移転施設の検討}

施設評価結果と耐用年数をもとに、前記で決定した機能ごとの削 減目標面積に到達するまで、以下にしたがって施設ごとの活用方法 を決定した。表 9 に 1 例として、教育文化機能における活用方法の 決定結果を示寸注 ${ }^{13)}$ 。活用方法決定の仕方は、「(1)複合化」は耐用年 数を迎えるまで 20 年以上あり、活用方針が「縮減的複合化利用」「長 期的複合化利用」の施設、「(2)建替」は 10 年以内に耐用年数を迎え、 活用方針が「長期的継続利用」「長期的複合化利用」の施設、「(3)廃止・ 移転」は(1) (2)満たさず、活用方針が「縮減的継続利用」「縮減的複 合化利用」「機能停止・移転」の施設とした。

\section{2）地域ごとの施設整備方法の決定}

1) で決めた施設ごとの活用方法をもとに、他施設の状況を考慮 した複合的な整備の計画を行う。ここでは、地域ごとの公共施設の 機能の状況、施設耐用年数、及び決定した施設活用方法を示した「経 時的地域実態マップ」を作成し、施設整備を複合的に計画する注 ${ }^{14)}$ 。 表 10 に示寸通り、立地タイプ・活用方法・周辺公共施設の状況を 考慮し、整備方法を計画した注15)。地区 1 における経時的地域実態マッ プ及び計画した整備方法を表 11 に、地区 1 における施設の立地と活 用方針をプロットしたものを図8示す。

地区 1 では、武蔵岡中学校区の武蔵岡中と大戸小が 2033 年に耐用 年数を迎え、「廃止・移転」が検討されている。武蔵岡中と大戸小学校 の学校教育機能と子育て支援機能は、この中学校区内のバランスを見 ると残す必要があり、図 8 の地図上で $2 つ の$ 位置関係を確認し、これ ら施設の「複合化建替」を計画した。また、堺中学校区の子どもセンター ぱおにおいては複合化が検討されている。改修時期に耐用年数を迎 える他の施設は堺市民センターとこうさぎ保育園となる。堺市民セ ンターは「廃止・移転」が検討されているが同学校区内に同機能が ないことから機能を残寸必要があり、これらの施設の立地も近いこ とから「複合化改修」を計画した注16)。

3) 町田市全体から見た施設整備方法の序列化

計画した地区 1 〜地区 5 までの施設整備方法を羅列し、町田市全体 として序列化を行ったものを表 12 に示す。表中の整備実行期間は、整 備対象施設が而用年数を迎える時期を反映している。

本研究では以下のように序列化する方法を決定し、町田市全体とし ての施設整備計画を検討している。
表 7 町田市の概要と将来的な状況予測注9

\begin{tabular}{|c|c|c|c|c|c|c|}
\hline \multicolumn{3}{|c|}{ 自治体名 } & \multicolumn{2}{|c|}{ 面積 } & \multicolumn{2}{|c|}{ 人口密度 } \\
\hline \multicolumn{3}{|c|}{ 町田市 } & \multicolumn{2}{|c|}{$71.65 \mathrm{~km}^{2}$} & \multicolumn{2}{|c|}{5,980 人 $/ \mathrm{km}^{2}$} \\
\hline \multirow{5}{*}{ 成 } & 項目 & \multicolumn{2}{|c|}{ 2014年 } & \multicolumn{2}{|c|}{ 2050年 } & 変動割合 \\
\hline & 棇人口 & \multicolumn{2}{|c|}{ 426, 336人 } & \multicolumn{2}{|c|}{ 418, 798人 } & $98 x$ \\
\hline & 老年 & \multicolumn{2}{|c|}{ 57,569人 } & \multicolumn{2}{|c|}{144,423 人 } & $138 \%$ \\
\hline & 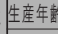 & \multicolumn{2}{|c|}{264,406 人 } & \multicolumn{2}{|c|}{231,977 人 } & $88 \%$ \\
\hline & 年少 & \multicolumn{2}{|c|}{104,361 人 } & \multicolumn{2}{|c|}{42,398 人 } & $74 x$ \\
\hline & 項目 & \multicolumn{2}{|c|}{ 過去5年平均 } & \multicolumn{2}{|c|}{ 2050年 } & 変動割合 \\
\hline & 歳入 & \multicolumn{2}{|c|}{1371 億0596万円 } & \multicolumn{2}{|c|}{ 1288億5694万円 } & $94 x$ \\
\hline & 歳出 & \multicolumn{2}{|c|}{ 1318億6774万円 } & \multicolumn{2}{|c|}{ 1288億5694万円 } & 98x \\
\hline
\end{tabular}

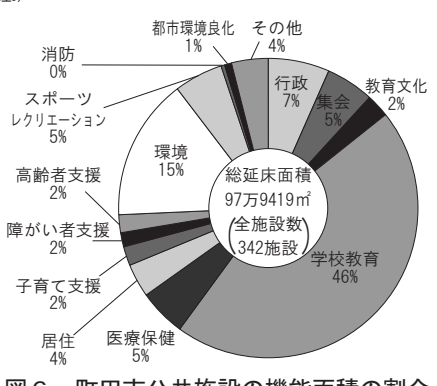

図 6 町田市公共施設の機能面積の割合

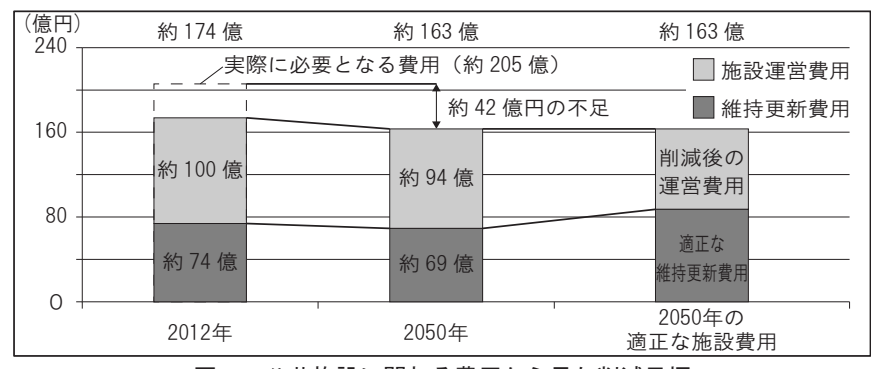

図 7 公共施設に関わる費用から見た削減目標

表 8 機能ごとの削減目標面積の決定

\begin{tabular}{|c|c|c|c|c|c|c|}
\hline \multicolumn{2}{|r|}{ 費用の項目 } & $\begin{array}{c}\text { 現在の費用 } \\
(円)\end{array}$ & \begin{tabular}{|c|} 
人口変動による \\
削減割合 \\
\end{tabular} & $\begin{array}{l}\text { 施設面積 } \\
\text { 削減割合 }\end{array}$ & $\begin{array}{c}\text { 削減目標面積 } \\
\left(\mathrm{m}^{2}\right)\end{array}$ & \begin{tabular}{|c} 
削減後費用 \\
(円)
\end{tabular} \\
\hline \multirow{15}{*}{$\begin{array}{l}\text { 施 } \\
\text { 運 } \\
\text { 賞 } \\
\text { 解 }\end{array}$} & 行政機能 & $261,777,042$ & $98 \%$ & $90 \%$ & -6303 & $235,599,338$ \\
\hline & 集会機能 & $1,571,781,525$ & $98 \%$ & $70 x$ & -14873 & $1,100,247,067$ \\
\hline & 教育文化機能 & $1,435,787,443$ & $98 \%$ & $70 \%$ & -7331 & $1,005,051,210$ \\
\hline & 学校教育機能（小学） & $550,721,258$ & $74 \%$ & $70 \%$ & -82002 & $385,504,881$ \\
\hline & 学校教育機能（中学） & $294,339,058$ & 74\% & $70 \%$ & -49004 & $206,037,341$ \\
\hline & 医療保健機能 & $41,084,866$ & $98 \%$ & $100 \%$ & 0 & $41,084,866$ \\
\hline & 居住機能 & $77,815,799$ & $98 \%$ & $90 x$ & -3499 & $70,034,219$ \\
\hline & 子育て支援機能 & $1,748,929,806$ & $74 \%$ & $70 \%$ & -6488 & $1,224,250,864$ \\
\hline & 障がい者支援機能 & $990,466,760$ & $98 \%$ & $100 x$ & 0 & $990,466,760$ \\
\hline & 高齢者支援機能 & $161,602,900$ & $138 \%$ & $130 \%$ & 6248 & $210,083,770$ \\
\hline & 環境機能 & $2,018,740,685$ & $98 \%$ & $90 x$ & -14813 & $1,816,866,617$ \\
\hline & スポーツ・レクリエーション機能 & $838,071,000$ & 98\% & $90 \%$ & -5099 & $754,263,900$ \\
\hline & 消防機能 & 未把握 & $98 \%$ & $100 x$ & 0 & 未把握 \\
\hline & 都市環境良化機能 & 未把握 & $98 \%$ & $100 \%$ & 0 & 未把握 \\
\hline & その他 & 133,422 & $98 \%$ & $90 \%$ & -4563 & 120,080 \\
\hline & 宪更新費用（一部除く） & $10,570,000,000$ & $88 \%$ & $81 \%$ & -187727 & $8,544,023,205$ \\
\hline & 合計 & $20,561,251,564$ & - & - & -187727 & $6,583,634,117$ \\
\hline
\end{tabular}

表 9 施設活用方法の決定結果（例：教育文化施設）

\begin{tabular}{|l|r|r|r|r|c|c|}
\hline \multicolumn{1}{|c|}{ 施設名 } & 延床面積 & 竣工年 & 少化度 & 残存年 & 活用方針 & 活用方法 \\
\hline さるびあ図書館 & 1318 & 1972 & $63 \%$ & 8 & 長期的複合化利用 & (2)建替 \\
\hline 博物館 & 1410 & 1973 & $76 \%$ & 9 & 縮減的複合化利用 & (3)廃止·移転 \\
\hline 町田市市民文学館 & 2156 & 1978 & $79 \%$ & 14 & 長期的継続利用 & - \\
\hline 自由民権資料館 & 911 & 1986 & $67 \%$ & 22 & 縮減的継続利用 & (3)廃止·移転 \\
\hline 国際版画美術館 & 7840 & 1986 & $65 \%$ & 22 & 長期的複合化利用 & (1)複合化 \\
\hline 中央図書館 & 5262 & 1990 & $63 \%$ & 26 & 長期的複合化利用 & (1)複合化 \\
\hline 金森図書館 & 1500 & 2000 & $32 \%$ & 36 & 長期的複合化利用 & (1)複合化 \\
\hline
\end{tabular}

表10 施設整備方法の計画方法

\begin{tabular}{|c|c|c|c|c|}
\hline $\begin{array}{l}\text { 立地 } \\
\text { タイプ }\end{array}$ & $\begin{array}{l}\text { 活用 } \\
\text { 方法 }\end{array}$ & 計画時期 & 計画時期における周辺公共施設の状況 & 施設整備方法 \\
\hline 立地限定型 & - & 耐用年数超過時 & - & 建替 \\
\hline \multirow{5}{*}{ 分散型 } & \multirow{2}{*}{ 複合化 } & \multirow{2}{*}{ 改修時期 } & $\begin{array}{l}2 \mathrm{~km} \text { 以内に「建替」、「移転・廃止」が検討されてい } \\
\text { る施設、あるいは耐用年数を迎える施設かる }\end{array}$ & $\begin{array}{l}\text { 他施設との } \\
\text { 複合化改修 }\end{array}$ \\
\hline & & & $\begin{array}{l}2 \mathrm{~km} \text { 以内に「建替」、「移転・廃止」が検討されてい } \\
\text { る施設、あるいは耐用年数を迎える施設ない }\end{array}$ & $\begin{array}{l}\text { 単独での } \\
\text { 改修 }\end{array}$ \\
\hline & \multirow[b]{2}{*}{ 建替 } & \multirow{2}{*}{$\begin{array}{c}\text { 而用年数超過時 } \\
\text { の前後 } 5 \text { 年 }\end{array}$} & $\begin{array}{l}2 \mathrm{~km} \text { 以内に「建替」、「移転・廃止」が検討されてい } \\
\text { る施設、あるいは耐用年数を迎える施設がある } \\
\end{array}$ & \begin{tabular}{|l|} 
他施設との \\
複合化建替
\end{tabular} \\
\hline & & & $\begin{array}{l}2 \mathrm{~km} \text { 以内に「建替」、「移転・廃止」が検討されてい } \\
\text { る施設、あるいは耐用年数を迎える施設がない } \\
\end{array}$ & $\begin{array}{l}\text { 単独での } \\
\text { 建替 }\end{array}$ \\
\hline & $\begin{array}{l}\text { 廃止: } \\
\text { 移転 }\end{array}$ & 耐用年数超過時 & 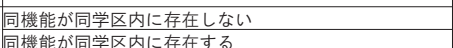 & \begin{tabular}{|l} 
建替 \\
廃止・移転
\end{tabular} \\
\hline \multirow{5}{*}{$\begin{array}{c}\text { 分散型 } \\
\text { 立地限定型 } \\
\text { 以外 }\end{array}$} & \multirow[b]{2}{*}{ 複合化 } & \multirow[b]{2}{*}{ 改修時期 } & $\begin{array}{l}\text { 同学校区以外にも「建替」「移転・廃止」が検討され } \\
\text { ている施設、あるいは耐用年数を迎える施設がある }\end{array}$ & $\begin{array}{l}\text { 他施設との } \\
\text { 複合化改修 }\end{array}$ \\
\hline & & & $\begin{array}{l}\text { 同学校区以外にも「建替」、「移転・廃止」が検討され } \\
\text { ている施設、あるいは耐用年数を迎える施設ない }\end{array}$ & $\begin{array}{l}\text { 単独での } \\
\text { 改修 }\end{array}$ \\
\hline & \multirow[b]{2}{*}{ 建替 } & \multirow{2}{*}{$\begin{array}{c}\text { 而用年数超過時 } \\
\text { の前後 } 5 \text { 年 }\end{array}$} & $\begin{array}{l}\text { 同学校区以外にも「建替」、「移転・廃止」が検討され } \\
\text { ている施設、あるいは耐用年数を迎える施設がある }\end{array}$ & $\begin{array}{l}\text { 他施設との } \\
\text { 複合化建替 }\end{array}$ \\
\hline & & & $\begin{array}{l}\text { 同学校区以外にも「建替」、「移転・廃止」が検討され } \\
\text { ている施設、あるいは耐用年数を迎える施設な゙い }\end{array}$ & $\begin{array}{l}\text { 単独での } \\
\text { 建替 }\end{array}$ \\
\hline & $\begin{array}{l}\text { 廃止. } \\
\text { 移転 }\end{array}$ & 耐用年数超過時 & - & $\begin{array}{l}\text { 廃止: } \\
\text { 校区を } \\
\text { 召えた移輬 }\end{array}$ \\
\hline
\end{tabular}


表11 地区1における経時的地域実態マップ及び計画した整備方法
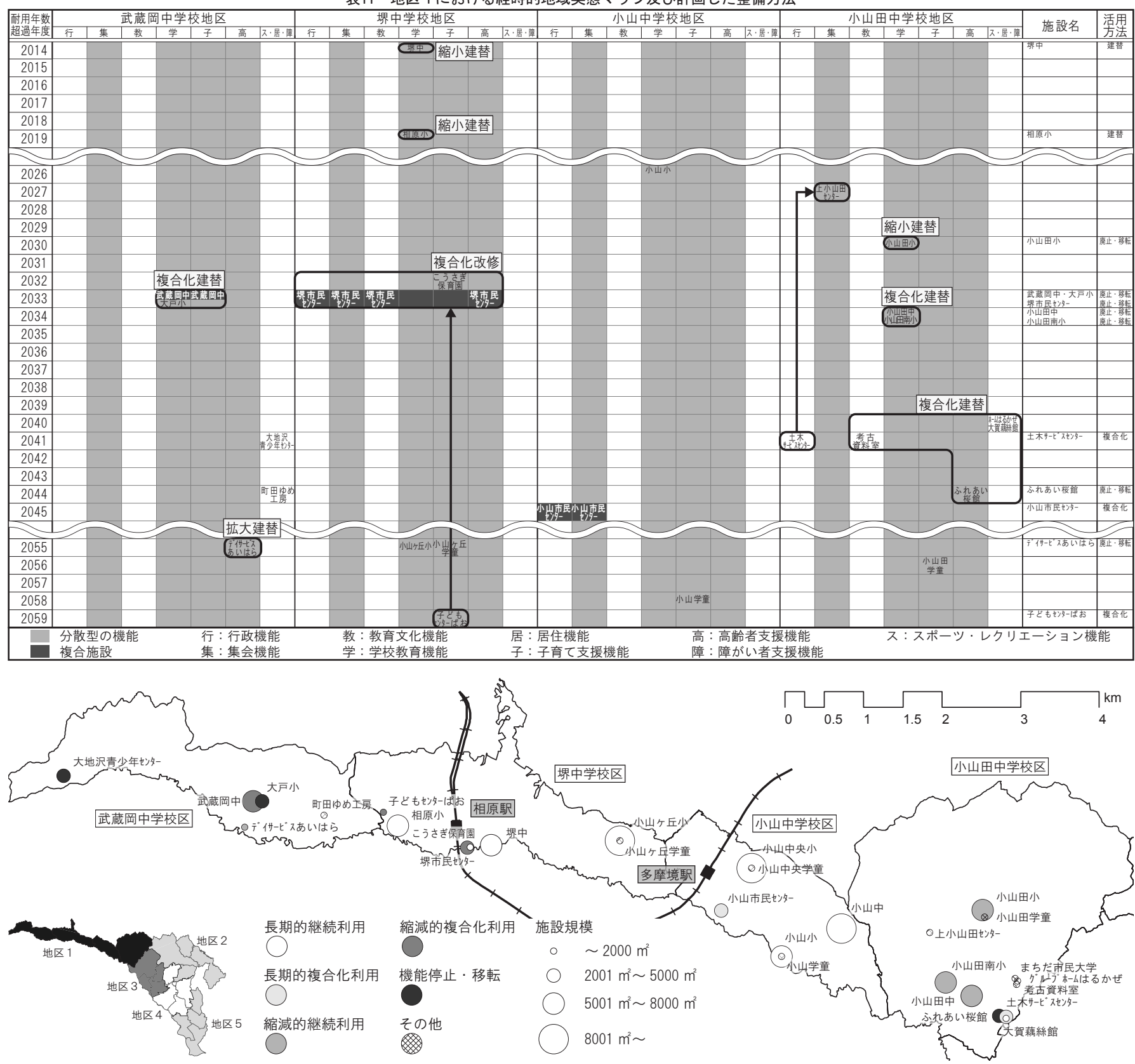

図８地区1における公共施設の立地と活用方針

(1)「同年度に 2 つ上にならないように整備」

(2)「劣化度が高い施設を含む整備方法を優先的に整備」

(3)「実行不能な整備方法は次年度に繰り越し」

また、整備後の施設面積は整備を実行する機能面積に「機能ごとの 削減目標面積の決定」において決定した機能ごとの削減割合の值 (表 8) を掛けて合計した面積として算出している。

（3）施設の削減結果とケーススタディの考察

表 13 に最終的な施設削減割合を示す。全 47 の整備方法の序列化し た結果、各年度ごとの計画を実行すると、2055 年には施設総面積が約 14 万 $\mathrm{m}^{2}$ 削減し、公共施設に関わる費用は約 22 億円の削減が見込まれる。

また、構築したプロセスの整備方法検討段階では、まず施設個別の 活用方法を決定し、次に地域ごとに施設の整備方法を計画、最後に自 治体全体としての整備方法を決定することで、施設再配置を考慮した 計画方法を実現できていると考えられる。

\section{5.まとめ}

本研究で得られた成果は、以下のとおりである。

1）品質・機能・立地の情報をそれぞれ棟・機能・施設ごとに整理し、 経時的な視点に立った評価方法を提案した。

2）経年数と外壁・内装・屋上防水・設備に対する最近の改修年を把 握することで、公共施設の劣化度を算出する方法を提案した。

3）公共施設耐用年数超過後の活用方針を決定し、地域でのロケーショ ンを把握することで、複数施設を同時に整備する方法を示した。

4）1）〜 3）より、現状で収集可能なデータを用いて、公共施設総量 適正化の第一段階となる自治体全体での整備計画を示した。

5）公共施設マネジメントを継続的に向上させていく、P D C A サイク ルに対応した段階的施設総量適正化に至るプロセスを示した（図 5 )。

今後は、提示したP D C A サイクルを回し、予測可能な財政・人 口状況等の情報を更新していくとともに、検証段階での住民意見の 
表12 施設整備方針の序列化

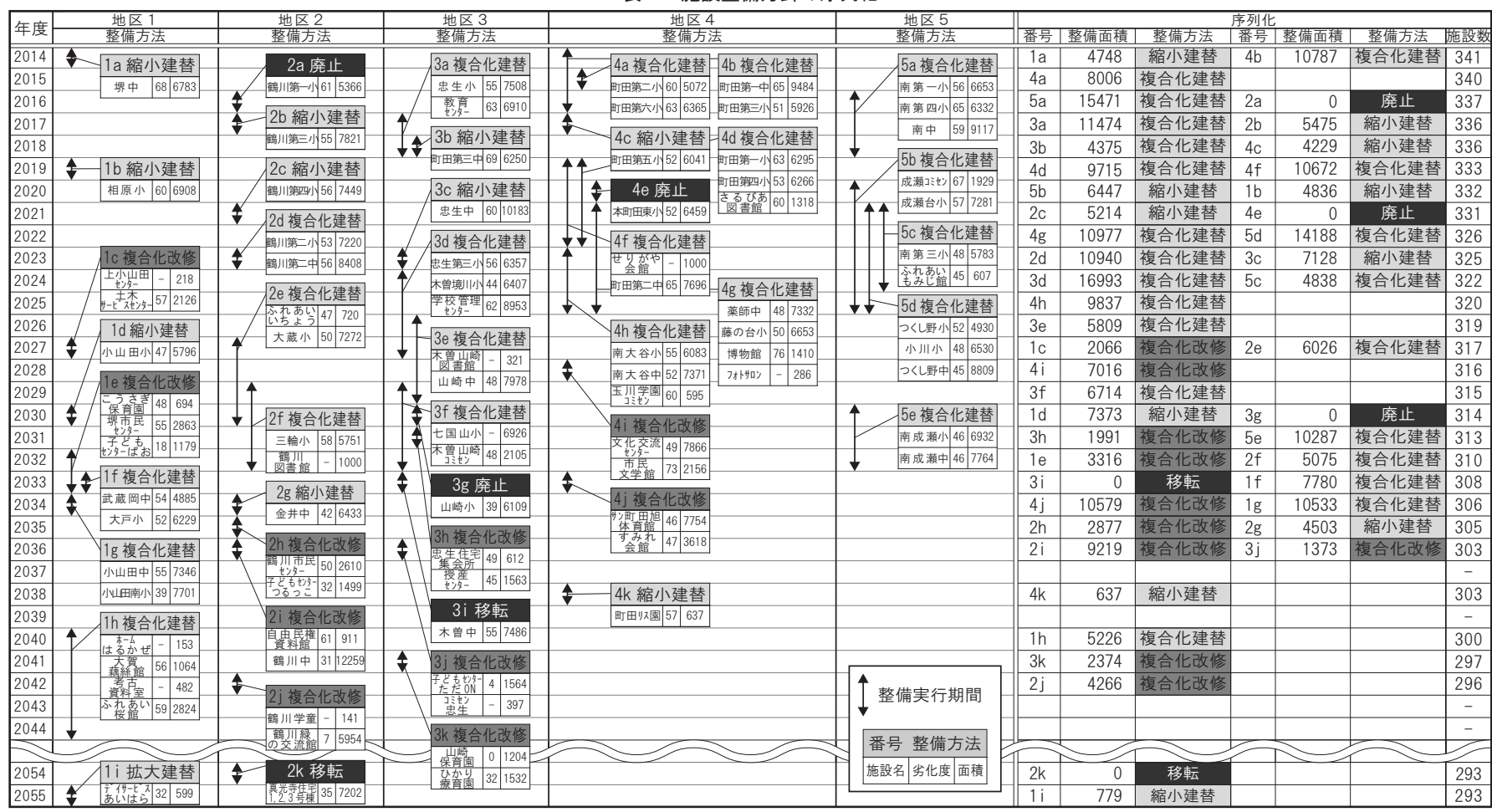

確認等から将来状況と住民意向に応じた施設総量削減策として、継 続的に見直していく必要がある。また、今回は中学校区にもとづい て検討を行ったが、各自治体のまちづくり方針に沿って地域を分割 することで、より将来のまちのあり方を踏まえた施設再配置と施設 総量適正化を検討可能と考える。

注

注1）2014年に総務省から発表され、人口変動と厳しい財政状況を踏まえ、公共 施設の更新・統廃合等に関する長期的且つ総合的な管理計画を求めたもの。

注2）2014年に国土交通省から発表され、持続可能な都市を実現するために、将 来のまちの在り方を見据えた公共施設の再配置を行うためのガイドライン。

注3） 1 つの公共施設において、複数建物及び複数の公共サービス（機能）を提 供している施設があることから、棟ごと、機能ごとで評価を行う。

注4）参考文献2）、3）の耐震性に関する判定では、建物の傾斜の有無・竣工 年・耐震補強の有無・Is值をもとに判断しているが、本研究では判定をよ り簡略化するため「建物の傾斜の有無」をフローから除外した。

注5）公共施設の劣化度判定をするため、参考文献5)の学校施設におけるの経年 ごとの改修費用の值を用いた。想定される修繥パターンにおいて最も望ま しい修繥を実施しているCase1「すべき十望ましい十事後保全」を用いた。

注6）劣化度は、経年により進むと推察され、各部位（外壁・内装・屋上防水・ 設備）の改修周期に対する改修実施年からの経年数の割合、及び而用年数 に対する経年数の割合を合わせて $100 \%$ になる算出式とした。また、各部 位の概算改修工事費が大きい順に重みづけし、判定では50\%を閾值とした。

注7）国立社会保障・人口問題研究所等から現況及び将来の人口メッシュデータ を入手し、施設から $1 \mathrm{~km}$ の同心円上の面積を按分し算出寸る。

注8）これらのデータは自治体で把握可能な情報及び、公的機関によって公開さ れている情報から整理を行っている。

注9）町田市人口統計、国立社会保障・人口問題研究所の将来人口統計より算出。

注10)施設運営費用は2012年の町田市公会計から算出、維持更新費用は工事履歷 をもとに2012年から過去11年分の平均值を用いた。公共施設に関わる費用 の推計値は、歳入の減少の割合と比例して隇少すると仮定し算出している。

注11) 維持更新費用は、施設建設などにより年度ごとにばらつきがあるため、 2012年までの過去11年間平均となる。

注12) 総務省らが開発、自治体が保有する公共施設の将来的に掛かる維持更新費 用を算出することができる。

注13) どの機能の施設においても同様の検討を行っている。

注14)計画に当たっては、一定規模で均等に区分けしている中学校区をもとに自
表13 施設の削減結果

\begin{tabular}{|c|c|c|c|c|r|}
\hline 年度 & 施設総面積 & 施設数 & 施設運営費用 & 維持更新費用 & 公共施設に関わる費用 \\
\hline 現時点 & 97 万 $9419 \mathrm{~m}^{2}$ & 342 & $9,991,251,564 円$ & $10,570,000,000 円$ & $20,561,251,564$ 円 \\
\hline 2055年 & 84 万 $2164 \mathrm{~m}^{2}$ & 293 & $9,226,129,064 円$ & $9,088,758,225 円$ & $18,314,887,290$ 円 \\
\hline
\end{tabular}

治体を分割して検討した。

注15）分散型の機能を移動する場合、公共サービスが低下する可能性があり、地 区内でのバランスを検討する必要がある。本研究では、移動距離が $2 \mathrm{~km}$ 以 内の範囲であらば、配置を移すこととした。

注16) 複合化移転が可能な施設がない場合は単独での改修となるが、施設面積に 変動がないため整備計画として定めていない。

\section{参考文献}

1) 首都大学東京 21 世紀COEプログラム地域公共施設ネットワーク再構築研究プ ロジェクトチーム：これからの地域公共施設整備一自己向上型地域公共施設 ネットワークの創生を目指してー, 2008

2）増川雄二：地方自治体における資産戦略策定に関する研究一保有施設全体把 握のための建物評価手法の提案一, 早稲田大学創造理工学部大学院建築学修 士論文, 2011

3）佐久間直哉 : 公共施設総量適正化に関寸る研究一施設再配置計画作成プロセ スの提案一, 早稲田大学創造理工学部大学院建築学修士論文, 2012

4）恒川淳基 : 公共施設の再整備手法に関寸る研究一施設の評価と整備方針の検 証一, 前橋工科大学大学院工学研究科建築学修士論文, 2013

5）川野紀江ら：名古屋市をモデルとした公共施設評価指標と再配置計画に関す る研究 その $1 \sim 3$, 日本建築学会大会学術講演梗概集, 建築社会システム, pp. 184〜188, 2012.9

6）恒川和久 : 公共施設におけるアクティビティの分析と考察一アクティビティ とキャパシティに着目した公共施設マネジメントに関する研究その1一, 日本建築学会計画系論文集, Vol.80, No.717, pp. 2617〜2624, 2015. 11

7）財団法人建築保全センター: 建築物のライフサイクルコスト, 2005.9

8）社団法人日本ファシリティマネジメント推進協会 : 青森県ライフサイクルコ ス卜試算手法及び施設評価手法開発業務報告書, 2006.2

9）総務省：地方財政状況調查関係資料 公共施設状況調経年比較表, 2012

10）か寸かべ未来研究所：公共施設の適正配置についての調査研究一最適な公共 施設配置の考察について一, 2014.3

11）国土交通省：まちづくりのための公的不動産（PRE）有効活用ガイドライン, 2014.4

12) 川崎市 : 川崎版 P R E 戦略 かわさき資産マネジメントプラン, 2011.2 


\title{
A STUDY ON PHASED OPTIMIZATION OF THE GROSS AREA OF PUBLIC FACILITIES VIA FACILITY RELOCATION
}

- Verification of the evaluation process and case studies in Machida-city -

\author{
Shunichi OHDATE ${ }^{*}$, Makoto TSUNODA ${ }^{* *}$ and Sangjun YI*** \\ * Urban Renaissance Agency, M.Eng. \\ ** Prof., Dept. of Architecture and Building Engineering, Graduate School of Urban Environmental Sciences, Tokyo Metropolitan Univ., Dr.Eng. \\ *** Assist. Prof., Dept. of Architecture and Environmental Design, Kanto Gakuin Univ., Dr.Eng.
}

It is necessary for local governments to evaluate the total number of public facilities in consideration of facility relocation. Owing to the aging of several public facilities and the change in future demographics, the financial situation is deteriorating. In 2014, the Ministry of Internal Affairs and Communications officially announced "Formulate the request of the public facilities comprehensive management plan," and the Ministry of Land, Infrastructure, Transport and Tourism published "PRE effective utilization guidelines for the town planning." Based on this, it is urgently necessary to consider relocation of facilities for the management of public facilities.

In this study, we categorized public facilities based on "building," "function," and "location" to create an evaluation method for public facilities based on previous research and evaluation methods. In the evaluation of buildings, we determined the degree of improvement that is required to improve earthquake resistance and the state of the outer walls, paint, and roof, of the building, as well as the associated equipment. In the evaluation of function, we determined whether the facility was operated at an appropriate cost and whether it provided sufficient public services. In the evaluation of location, we evaluated the convenience of the public facility in terms of traffic, and determined whether aggregation of facilities is valid at that location in the future. In addition, we developed a long-term utilization policy that considers utility after the completion of the useful life of the facility from these three evaluations.

Further, we propose a maintenance method for a group of public facilities via facility relocation, based on previous research and evaluation methods. In order to consider facility relocation, we constructed a process to consider a stepwise manner, such as facility, region, and entire municipality. In addition, it is possible for each municipality to collect the necessary data for the management of public facilities.

In order to verify the validity of the evaluation method and the constructed process, we conducted a case study on Machida-city. The working-age and youth populations of Machida-city are expected to decrease, whereas the elderly population is expected to increase. There are 342 public facilities here with a current total running cost of 17.4 billion yen. However, this cost is estimated to reach 16.3 billion yen by 2050. Further, in order to maintain the current number of public facilities, the actual cost, updated appropriately with maintenance costs, is 20.5 billion yen. Therefore, a shortage of 4.2 billion yen is expected in the future.

The case study results are as follows. The gross area of public facilities was reduced by approximately 140,000 m2. The facility costs can be expected to decrease to 18.3 billion yen. In other words, the reduction effect of the cost of public facilities can be called about 2.2 billion yen.

In conclusion, we proposed a long-term utilization policy that considers utility at the end of the useful life of a facility. Additionally, the maintenance method and total optimization process of the facility via facility relocation, which was validated by verification with the target local government, is presented. 